体青学研究，37：365-374，1993.

\title{
ラット偈部宙つクによるヒラメ筋線維組成およひミオシン重鎖の变化
}

$$
\text { 大石康 晴12) 山川孝2)* 宮 本 英 七²) }
$$

\section{Changes in fiber type composition and myosin heavy chain isoform in rat soleus muscles following hindlimb suspension}

\author{
Yasuharu Oishi ${ }^{1,2}$, Takashi Yamakawa ${ }^{2 *}$ and Eishichi Miyamoto ${ }^{2}$
}

\begin{abstract}
We investigated the changes in fiber type composition and myosin heavy chain isoform in rat soleus muscles during 7 -week hindlimb suspension. In the soleus muscles, a significant reduction of the muscle weight was observed after 3-week suspension, and the muscle fiber atrophy was found in both slow-twitch oxidative (SO) and fast-twitch oxidative glycolytic (FOG) fibers. This indicates that the decrease in the muscle weight was caused by the atrophy of both SO and FOG fibers. As for the fiber type composition, the percentage of FOG fibers increased in the soleus muscles after 3-week suspension, and concomitantly an increase in the fast type of myosin heavy chain isoform was also observed. These results suggest that the increase in the percentage of FOG fibers in the soleus muscles during hindlimb suspension was caused by the conversion from SO to FOG fibers, it is also suggested that the increase in FOG fibers reflected that of fast type of myosin heavy chain isoform. The speeding of the soleus muscles following hindlimb suspension was considered from both tissue level by histochemical analysis and molecular level by SDS-PAGE and immunobiochemical analysis.
\end{abstract}

Key words: fiber type composition, myosin heavy chain, hindlimb suspension, SDS-PAGE, immunoblotting

(Japan J. Phys. Educ., 37: 365-374, March, 1993.)

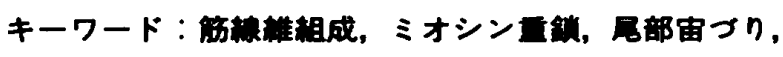
SDS-PAGE，イムノフロッティンク

\section{I. 緒}

骨格筋の㾏用性萎樎実呤モデルとしては， ラットやハムスターを用いた尾部宙づり実験ま たは全身の宙づり実験が挙げられる。このよう な実験モデルは，無重力状態を模做したモデル と考えられ，重力の除去あるいは軽減による筋 への影辡が検討されている，宙づりモデルの影
需を筋のサイズでみた場合，速筋線䊒よりも遅 筋線維の萎縮率が大きく，その結果，崌筋線䧽 占有率の高いヒラメ筋では筋重量の低下が影著 となり ${ }^{15)}$ ，速筋線維占有率の高い筋ではその影 整は比較的小さい24).また，筇の収縮特性への影 管をみた場合，ヒラメ筋で収縮時間および弛緩 時間の短縮が認められ 報告されている。このことは，組織化学的分析 により筋線䊒組成の变化を検討したとき，収樎 速度の速い速筋線䊒の占有率が增加したことか
1) 篗本大学教童部保健体育科数室

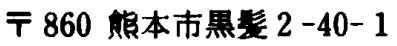

2) 筧本大学医学部来理学教室 于 860 筫本市本萍 2-2-1

・現住所：北海道千藏市梅ヶ丘, 梅ヶ丘クリニック
1. Department of Physical Education, Faculty of General Education, Kumamoto University. 2-40-1 Kurokami, Kumamoto-city, Kumamoto (860)

2. Department of Pharmacology, Kumamoto University Medical School. 2-2-1 Honjo, Kumamoto-city, Kumamoto (860) 
らす推察される ${ }^{9,13)}$.

骨格筋線維の収縮速度はミオシンの ATPase (ATP 加水分解酵素) 活性により規定 され2), 筋線維は, この ATPase 活性の $\mathrm{pH}$ 依存 性の差に基づき，組織化学的に遅筋線維といく つかのサブタイプを持つ速筋線維に分類され る。速筇線維は，遅筋線維と比較して収縮速度 が速く，ATPase 活性が高い特性を有してい る。また，生化学的分析により，収縮速度を决 定するミオシンのATPase はミオシン分子の 重鎖 (myosin heavy chain: HC) 部分に含有 されることが報告27されている. SDS-ポリアク リルアミドゲル電気泳動法を用いた研究から, このミオシン重鎖には遅筋型（HC-I）と速筋型 (HC-IIa，HC-IIb) の分子種（フインフォーム） が存在し，遅筋線維である Type I 線維には HC-I が, 速筇線維の Type IIa, Type IIb の各 線維にはそれぞれ HC-IIa，HC-IIb が特異的に

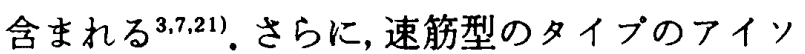
フォーム（HC-IIa，HC-IIb）含有量が高い筋線 維ほど収縮速度が速いことが報告されてい る23).したがって，組織化学的に分類される速筋 線維と遅筋線維では, 蛋白レベルにおいてミオ シン重鎖アイソフォームが異なって扣り，これ が筇線維の収縮特性を規定していると考えられ る。そこで宙つりにより認められるヒラメ筋の 収縮速度の変化や速筋線維占有率の増加を, 筋 細胞内の蛋白レベルにおけるミオシン重鎖アイ ソフォームの変化の観点から検討することは意 義深いと思われる。

本研究はラット尾部宙つりによるヒラメ筋の 変化を, 組織レベルでは能線維組成の変化, 蛋 白レベルではミオシン重鎖フイソフォームの変 化からそれぞれ分析し，各々のレベルに拈ける 変化の様態，およびその関連性について検討し た. 従来,ミオシン重鎖分析にはSDS-ポリアク リルアミドゲル電気泳動法が用いられてきた が，アイソフォームの分子量が近似しているた め分離には手法上の困難さが伴ってきた。本研 究では，ミオシン重鎖分析のための新しい手法 として, 速笳型タイプのミオシン重鎖のみを認
識するモノクローナル抗体による抗原抗体反応 を利用したイムノブロッティング法により免疫 学的分析を行った。

\section{II. 方 法}

実験には生後 13 週龄のウイスター系雄性 ラット 42 匹を用い, 各 21 匹をコントロール群 と宙つりり群とした．宙づりは Morey ${ }^{18)}$ の方法に したがい，尾部を上方に引き上げ後肢を中空に 浮かせることにより行った。この方法では, ラッ 卜は前肢を使って 360 度動くことが可能であ る。な招慨と水は両群とも自由摄取とした， 7 週間の実験期間中, 各週毎に両群より 3 匹ずつ を分析に供し，被検筋として左右ヒラメ筋を用 いた。

\section{1. 組織化学的分析}

組織化学的分析には左脚ヒラメ筋を用いた。 エーテル麻酔の後筋を取り出し, 筋重量を測定 した後，約 $5 \mathrm{~mm}$ の厚さで筋腹付近を切り出 し，これをコンパウンド内に埋め液体窒素で泠 却したイソペンタンで凍結した。 $-20^{\circ} \mathrm{C}$ の環境 下でミクロトームを用いて厚さ約 $10 \mu \mathrm{m} の$ 連 続切片を作成した。これらの連続切片にミオシ ソATPase 染色 ${ }^{20)}$ 扎よび NADH-TR 染色 ${ }^{19)}$ 施し, Peter et al. ${ }^{22)}$ の分類に従い, 筋線維を SO (slow-twitch oxidative) 線維と FOG (fasttwitch oxidative glycolytic）線維に分け，平均 816 本の笳線維を用いて筋線維組成を求めた。 また，それぞれの筋線維約 40 本ずつについて， コンピューター $(\mathrm{MZ}-80 \mathrm{Z})$ に接続したデジタイ ザー（MITABLET-II，KD 8030)を用いて横断 面積を算出した。

\section{2. ミオシン重鎖分析}

ミオシン重鎖分析には右脚ヒラメ筋を用い た。 ヒラメ筋重量を測定し，その 9 倍量のトリ スバッファー溶液 (10 mM Tris- $\mathrm{HCl} ， 250 \mathrm{mM}$ sucrose, $1 \mathrm{mM}$ EGTA, $1 \mathrm{mM}$ EDTA, $1 \mathrm{mM}$ PMSF, pH 7.5)でホモジートし, Bradford ${ }^{5)}$ の方法に従って蛋白定量を行い, $2.5 \mu \mathrm{g}$ の蛋白 を電気泳動に供した。電気泳動は，Laemmli ${ }^{16)}$ の方法により， $5 \%$ 濃樎ゲル， $7 \%$ ランニング 
ゲルを用いて， $30 \mathrm{~mA}$ で約 3 時間の SDS-ポリ フクリルアミドゲル電気泳動（以下 SDSPAGE と略す) を行った後, Towbin et al. ${ }^{34)} の$ 方法に従いトランスブロットシステムにより泳 動ゲル内の蛋白をミリポフーメンブレン（ミリ ポアーフィルター, GVHP 000-10)に転移した $(50 \mathrm{~V}, 16-20 \mathrm{~h})$. 転移後, 速筋型ミオシン重鎖 に対するモノクローナル抗体を用いたイムノブ ロッティングを行い, 速筋型ミオシン重鎖のバ ンドを免疫染色した。すなわちこのメンブレ ンを室温で 1 時間, ウシ血清アルブミン溶液 (2.5\% Bovine serum albumin, SIGMA A2153, 0.1 M Tris- $\mathrm{HCl}, 0.15 \mathrm{M} \mathrm{NaCl}, \mathrm{pH} 7.5$ ) に浸し，抗体の非特異的結合部位をブロックし た後，室温で 1 時間，1 次抗体としてマウスの モノクローナル抗ミオシン速筋型重鎖抗体 (monoclonal anti-myosin, fast skeletal antibody, SIGMA, M-4276) と反応させ，さらに 2 次抗体としてビオチン化抗マウス抗体 （Vectastain ABC kit，VEC K-4002）と室温で 30 分間反応させた。各反応の間にメンブレンを TTBS 溶液 $(0.1 \mathrm{M}$ Tris- $\mathrm{HCl}, 0.9 \% \mathrm{NaCl}$, $0.1 \%$ Tween 20, pH 7.5) で洗浄し，余分な抗 体を除去した。メンブレンに転移された速筋型
ミオシン重鎖のバンドは, ジアミノベンチジン (3,3'-diaminobenzidine, SIGMA D-5637) を基 質として，アビジンービオチンーペルオキシ ダーゼ複合体法（Vecta-stain ABC kit, VEC K-4002）により免疫染色した。

\section{3. 統計処理}

各群の平均值の差の検定は, student t-test に より行い, $5 \%$ 未満の危険率を有意水淮とした。

\section{III. 結果}

\section{1. 筋重量の減少およひ筋線維㻺粨}

Fig. 1 に実験期間中の各週におけるコント ロール群と宙づり群のラットヒラメ筋の平均筋 重量を示した。コントロール群では，時間経過 とともに 6 週間目まで筋重量はわずかに増加し た．宙つり群では，2 週目までは筋重量の変化 を認めなかったものの， 3 週目以降より 7 週目 まで筋重量の顕著な減少が認められた。その低 下率は 45.5一68.0\%を示し，コントロール群に 比べ有意に低値であった．Fig. 2 には各週ごと の両群七ラメ筋の SO 線維と FOG 線維の横断 面積を示した。宙づり群では，宙づり 2 週目ま では，測定值の変動が大さくコントロール群と の差はみられなかったが， 3 週目以降より両線

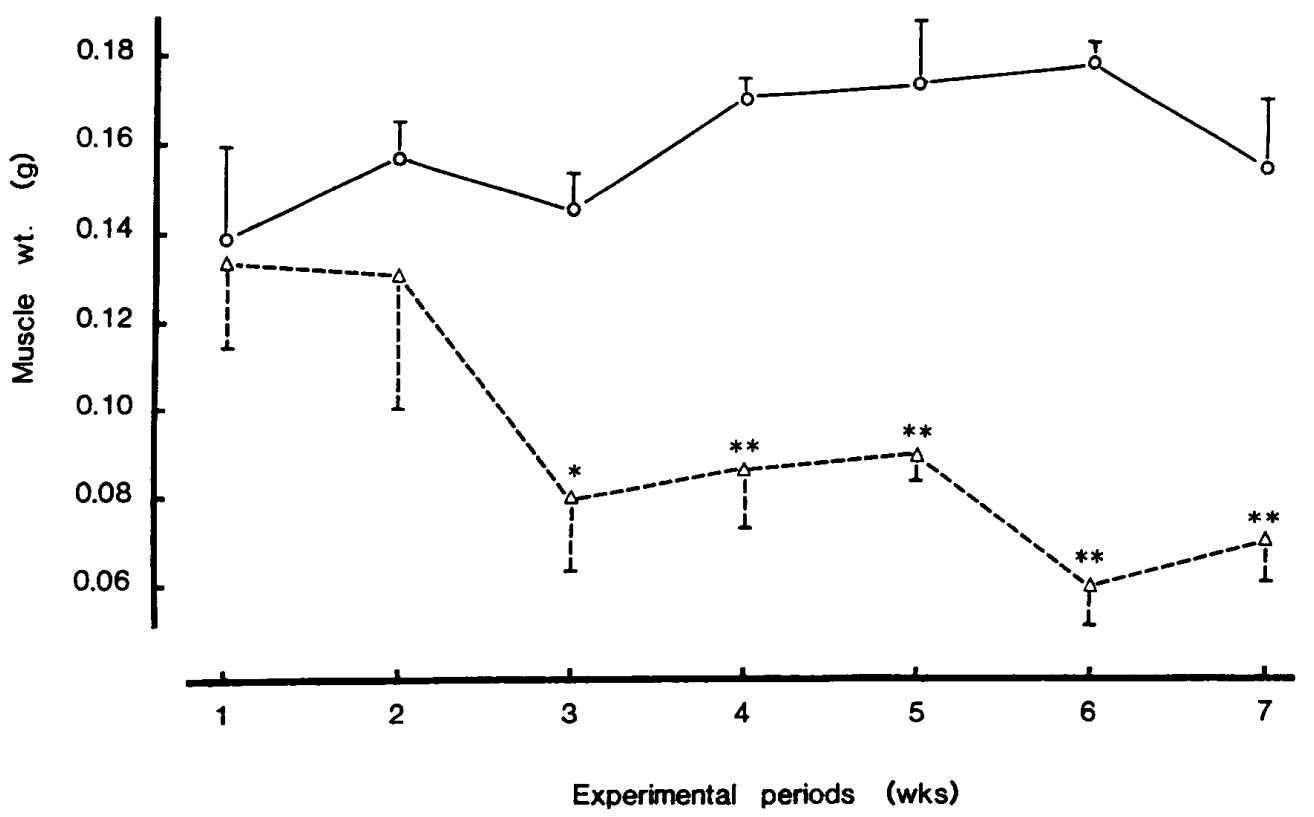

Fig. 1. Changes in muscle weight in control $(\bigcirc)$ and suspension $(\triangle)$ groups. Values are means $\pm \operatorname{SD}(n=3) .{ }^{*} p<0.05,{ }^{* *} p<0.01$ compared with control. 
維ともにコントロール群に対し横断面穔の有意 な減少を示した，宙つり群の両筋線雃の萎縮率 を比較すると，宙づり 3 週目より 7 週目までの SO 線䊒の萎樎率は 56.7-72.2\%であり，一方 FOG 線維では，41.8一60.5\%の萎縮率を示し た。実験期間を通して両線維の萎縮過程，およ び筋重量の減少と筋線雃横断面䅪の減少は類似 した経時的变化を示し，本実䋡モデルにおいて， 宙づり 3 週目以降に確実にヒラメ筋の廃用性萎 縮が生じることを示した。

\section{2. 筇綵維組成}

コントロール群と宙つり群の筋線維組成の経
時的変化を Table 1 に示した。両群とすにヒラ 入筋はSO 線維と FOG 線雄から構成されてお クコントロール群では実験の全過程を通して FOG 線䊒は数\%しか認められなかった。これに 対して宙づり群では，2 用目までは筋線䊒組成 に有意な変化は認められなかったが， 3 週目以 降ほぼ全てのヒラメ筋において FOG 線雃の占 有率は $10 \%$ を越え，宙づりによる FOG 線維占 有率の顕著な增加がみられた。これは、ラット 尾部宙づりによりヒラメ筋の筋線茎全体が萎樎 する一方でFOG 線維の割合が増加し，筋の収 縮機能の観点からはヒラメ筋が速筋化したこと

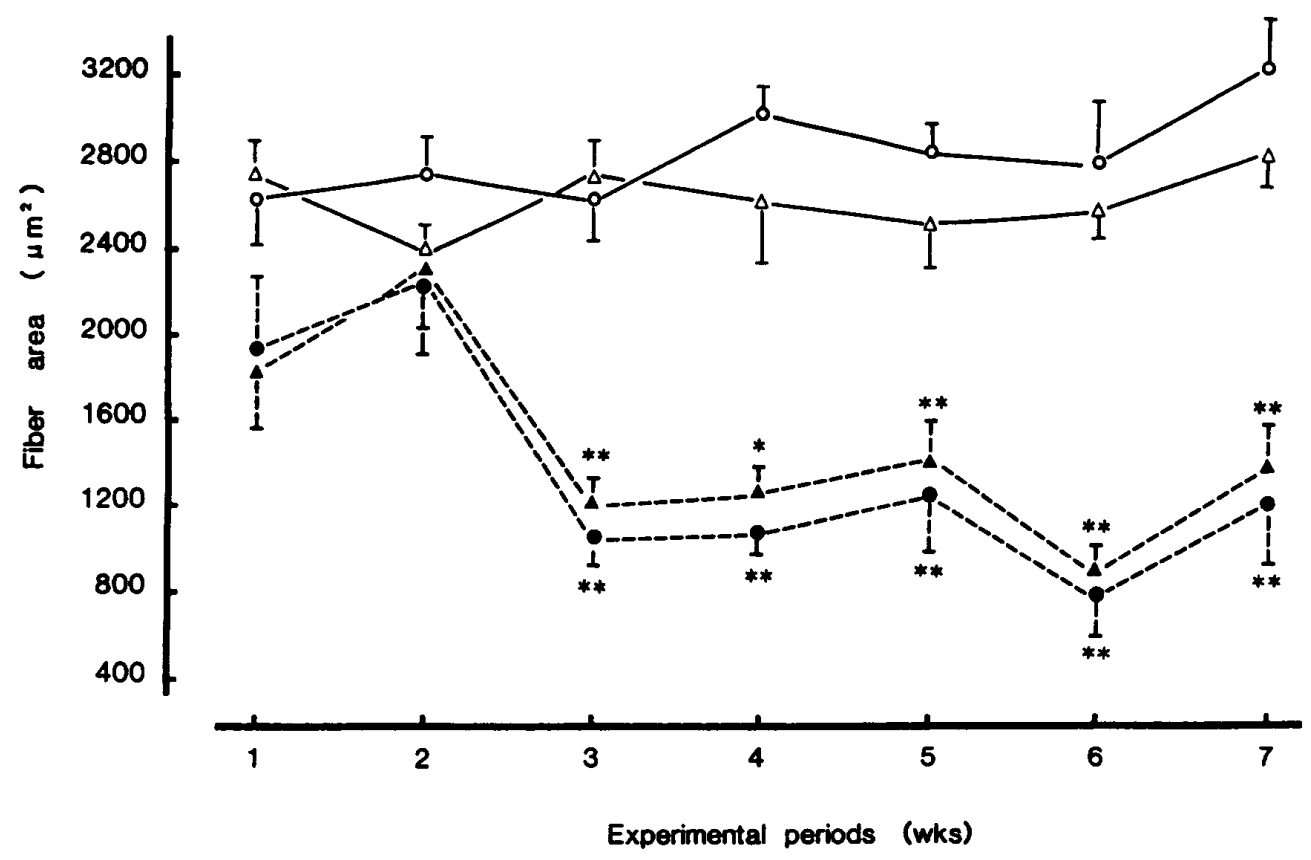

Fig. 2. Changes in muscle fiber area in control and suspension groups. $\bigcirc$ : control SO fibers, $\triangle$ : control FOG fibers, $:$ suspended SO fibers, $\Delta$ : suspended FOG fibers. Values are means $\pm S D(n=3) .{ }^{*} p<0.05,{ }^{* *} p<0.01$ compared with control.

Table 1. Fiber type composition of soleus in control and suspension groups (\%).

\begin{tabular}{lrrrrrrr}
\hline Exp. period & 1 wk. & 2 wk. & 3 wk. & 4 wk. & 5 wk. & 6 wk. & 7wk. \\
\hline Control & & & & & & & \\
SO & $94.4 \pm 3.1$ & $95.2 \pm 1.3$ & $95.6 \pm 1.2$ & $97.3 \pm 0.9$ & $96.3 \pm 2.0$ & $94.8 \pm 1.8$ & $98.2 \pm 0.7$ \\
FOG & $5.6 \pm 3.1$ & $4.8 \pm 1.3$ & $4.4 \pm 1.2$ & $2.7 \pm 0.9$ & $3.7 \pm 2.0$ & $5.2 \pm 1.8$ & $1.8 \pm 0.7$ \\
\hline Suspension & & & & & & & \\
SO & $94.6 \pm 0.5$ & $93.6 \pm 2.7$ & $85.0 \pm 4.4^{*}$ & $89.7 \pm 2.7^{*}$ & $68.5 \pm 8.8^{*}$ & $80.4 \pm 6.4^{*}$ & $73.6 \pm 8.0^{*}$ \\
FOG & $5.4 \pm 0.5$ & $6.4 \pm 2.7$ & $15.0 \pm 4.4^{*}$ & $10.3 \pm 2.7^{*}$ & $31.5 \pm 8.8^{*}$ & $19.6 \pm 6.4^{*}$ & $26.4 \pm 8.0^{*}$ \\
\hline
\end{tabular}

Values are mean $\pm \mathrm{SD}(\mathrm{N}=3) . * \mathrm{p}<0.05$ compared with control. 
を示している.

以上の結果で観察されたように，本実験の宙 づりモデルでは, ヒラメ筋の筋萎箱, 筋線維組 成の変化ともに尾部宙つうり 3 週目以降に顕著で あった。

3. ミオシン五鎖 (myosin Heavy Chain: $\mathrm{HC})$

ミオシン重鎖については, SDS-PAGE 後イ ムノブロット法により抗ミオシン速筋型重鎖抗 体を用いて速筋型のミオシン重鎖フインフォー ムを検出することにより分析を行った。なお， 本抗体の反応性については，5-8\%の漊度勾 配のついた分離ゲルを用いた SDS-PAGEによ り確認した（Fig. 3)。 ヒラメ筋と腓腹筋のミオ シン重鎖を分析した結果，ヒラメ筋では 2 本の ハシンド(HCI, IIa, Fig. 3B)が，腓腹筋では 3 本のバンド (HCI, IIa, IIb, Fig. 3C) がそれ ぞれ認められた。 これらのミオシン重鎖フイン フォームに対する抗ミオシン重鎖抗体の反応性 を検討したところ，速筋型アイソフォームのみ を認識することが確認された(Fig. 3E，F)。コ
ソトロール群と宙づり群の全てのラットヒラメ 筋についてこの抗体を用いて分析し，各週ごと の速筋型ミオシン重鎖の泳動ハターンを Fig. 4 に示した。 コントロール群 (Fig. 4B) では実 験初期の段階で数匹のラットのみにわずかに速 筋型ミオシン重鎖が認められたにすぎなかっ た。これに対し，宙づり群 (Fig. 4A) では宙づ り 3 週目を境に全てのラットにおいて速筋型 ミ オシン重鎖の顕著な增加が認められた。

IV. 考寀

骨格筋の不使用・不活動に対する影慗は，形 態的には筋の萎縮か，機能的には遅筋の速筋化 が挙げられ，その影䛚は速筋よりもヒラメ筋の ような遅筋に顕著である。このような変化は， ラットの尾部宙づり実絤のみならず，宇宙飛行 実験においても同様な変化が認められること吾 から，重力の除去あるいは軽减により生じたも のと考えられる。したがって，抗重力筋のヒラ メ筋に顕著な変化が認められることは妥当な結

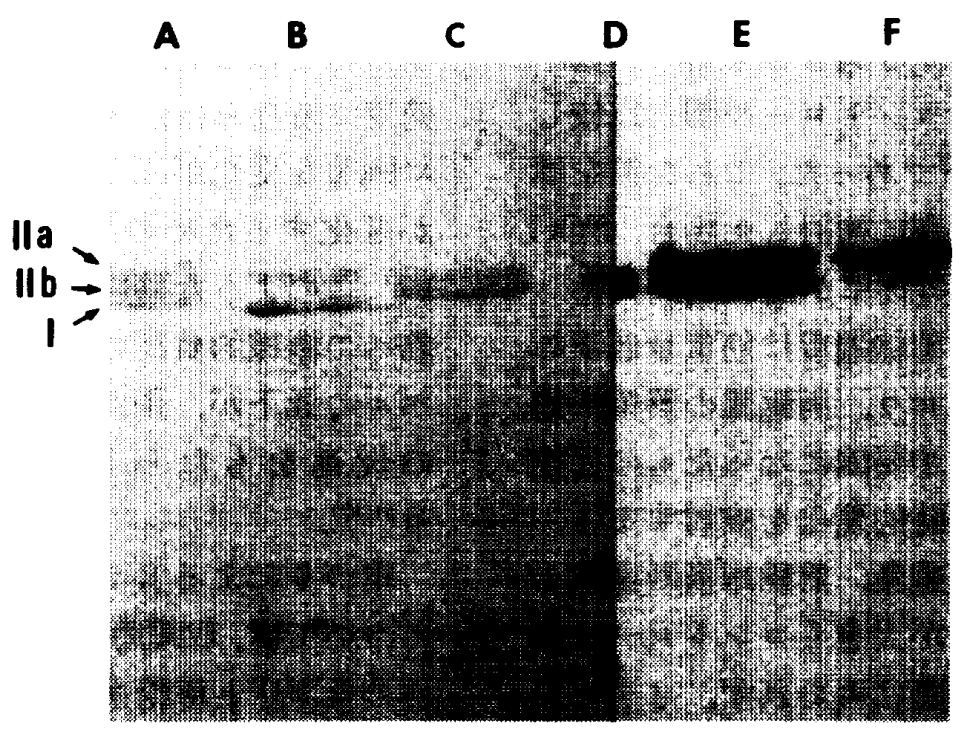

Fig. 3. Immunoreactivity of various types of heavy chains for anti-fast myosin monoclonal antibody to rat skeletal muscle. Ila, Heavy chain IIa; IIb, Heavy chain IIb ; I, Heavy chain I ; A.D, Amido black staining ; D.F, Immunostaining ; A and E, soleus + gastrocnemius ; B and F, soleus ; C, gastrocnemius ; D, $200 \mathrm{~K}$ molecular weight marker; The antibody reacts with only the fast type of myosin heavy chains IIa and IIb. SDS-PAGE was performed using 5-8\% gradient running gel. 


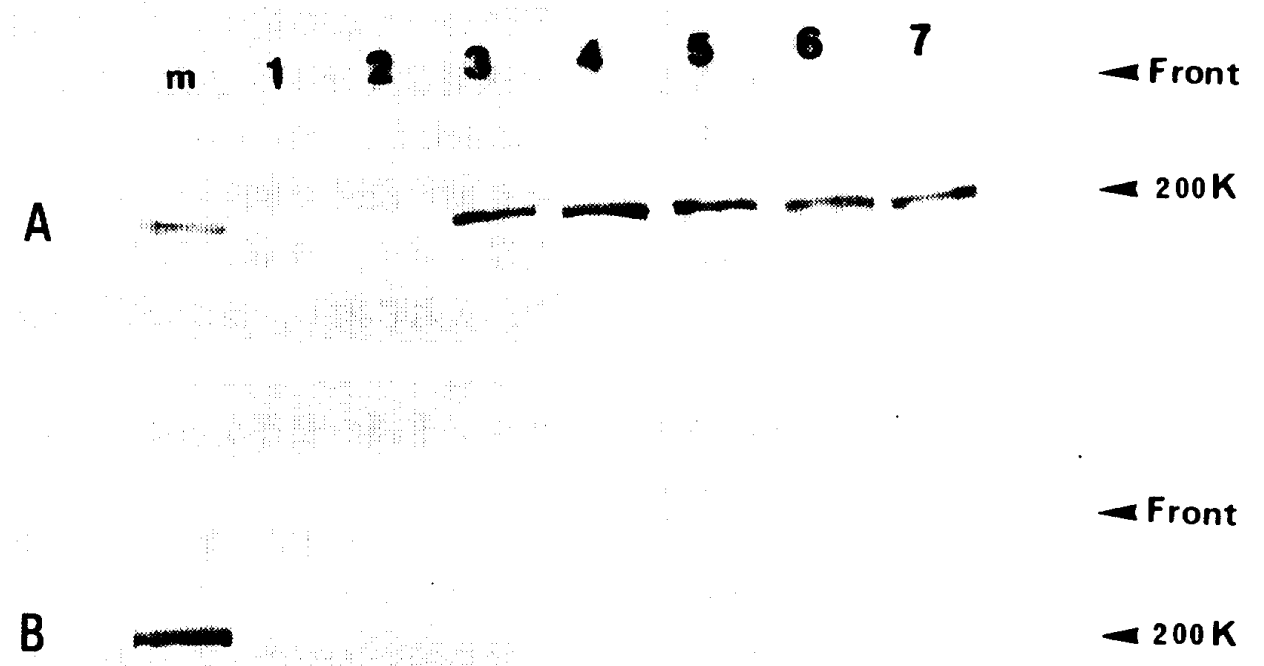

Fig. 4. Immunoblotting of myosin heavy chain with the anti-fast myosin heavy chain monoclonal antibody. Lane A, suspended soleus; lane B, control soleus; $\mathrm{m}, 200 \mathrm{~K}$ molecular weight marker ; $1-7$, each represent $1-7$-week suspension periods.

果といえる.このヒラメ筋について， 7 週間の ラット尾部宙づりに対する影響を，組織レベル と蛋白レベルから分析, 検討した.

形態的な筋の萎樎に関して，本研究で用いた ヒラメ筋重量は, 宙づり 3 週目より著しい低下 がみられ，その範囲はコントロール群と比較し て 45.5-68.0\%の低下であった。これを筋を構 成する筋線維のタイプ別に検討した場合, FOG 線維に比べ SO 線維の萎樎率が高い傾向にあっ たが，両線維タイプの萎縮過程は筋重量低下の 経時的変化と類似しており, 両線維の萎縮が筋 重量の低下を引き起こす要因になったすのと推 察される，筋萎縮の経時的変化を検討すると， 宙づり 2 週目までは能重量, 筋線維横断面積と もに個体間のばらつきが大きくコントロール群 と宙つり群では有意な差はみられず，3 週目以 降に著しい筋の萎縮を示した，実験期間中のあ る時期を境に筋に顕著な变化が認められたこと の説明のひとつとして，筋に慢性的電気刺激を 加え, そのミオシン軽鎖の变化を検討した Seedorf et al. ${ }^{26)}$ の報告が挙げられる。彼らは, 160 日間の連続電気刺激の結果, 刺激 60 日から
90 日の間にミオシン軽鎖の著しい変化がみら れたことから，筋はある一定量以上の刺激を負 荷してはじめて变化が生じると主張し，筋には 変化が生じるための負荷刺激の量的閏值が存在 するのではないかと推察している。この考えを 適用するならば，本結果より宙づり 3 週目以降 に顕著な变化がみられたことは，この期間に筋 が変化するための闒値に達したのかもしれな い。このような筋線䊒の萎縮は，宙づりによる 筋一の機械的負荷の除去, あるいは筋の活動レ ベルの低下が，蛋白合成速度の抑制，分解速度 の促進をもたらしたものと推察されてい $3^{14,33)}$.

宙つうりによるヒラメ筋の機能的側面への影響 については, 収縮時間の短縮 ${ }^{28,30)}$, 酸化系酵素活 性の低下 ${ }^{111}$ と解糖系酵素活性の増加 ${ }^{13)}$ ，および 速筋線維占有率の増加 ${ }^{6,8,9)}$, 速筋タイプのミオ シン分子の増加 ${ }^{10.12)}$ な゙が報告されている。こ れらの報告は, 宙づりによるヒラメ筋の速変化 を示唆するすのである。本研究では，ヒラメ筋 の筋線維組成を分析した結果, コントロール群 では実験期間を通して FOG 線維の占有率はほ 
ぼ一定で，1.8一5.6\%の低值を示した。これに 対し, 宙つうり群では, 宙づり 3 週目よりFOG 線 維占有率の増加が認められた。この結果は, こ れまでの報告と同様にヒラメ筋の速筋化を示し ている。このような FOG 線維占有率の增加に ついてはいくつかのメカニズムが考えられる.

すなわち, (1) SO 線維から FOG 線維への筋線 維のタイブ移行，（2）SO 線維の選択的な消失 による相対的な FOG 線維の増加，（3）FOG 線 維の新生である。(1)のタイプ移行について論じ る際には，筋線維の総数が実験の前後で変化し ていない。または実験群とコントロール群で差 が認められないことが必要条件となる。この点 に関し, Templeton et al. ${ }^{311}$ は， 4 週間の宙づり 後に Type IIa 線維の増加がみられたラットヒ ラメ筋を用いて，硝酸消化法により直接筋線維 総数を求めたところ，コントロール群と宙づり 群で差がないことを報告している。さらに蛋白 レベルにおいて胎児期, 新生児期のミオシン分 子が認められないことから(3)の筋線維の新生 の可能性を否定し, (1)のタイプ移行の可能性を 主張している. Corley et al. ${ }^{6)}$ 。， 4 週間の宙つ り後, ヒラメ筋の組織標本から筋線維総数を算 出し、コントロール群と宙づり群に差がないこ とから同様な可能性を示唆している.（2）SO 線維の選択的消失については，ラットの下肢固 定実験ではその可能性を示唆した報告4がみら れるが, 本研究で行った宙づりモデルでは，SO 線維の選択的消失の可能性はほとんどないと考 えられる、それは，本研究においても先行研究 にみられるようにSO 線維が FOG 線維に比べ て萎縮率では高い傾向にあったものの，実際の 横断面積は両線維で差がないこと, さらに実験 期間を通して両線維の萎縮過程は類似してお ク，SO 線維のみが選択的に萎樎し消失したと は考えにくいなどの理由による，以上のことか ら, 本研究において, 宙つうりヒラメ筋にみられ る FOG 線維占有率の増加は, タイプ移行の可 能性が最も高いと考えられる。しかしながら， これは組織化学的分析を基にした推察であり， 他のメカニズムの可能性を完全に否定すること
はできない，従ってより詳細な検討を行らため にはさらにミクロな分子生物学的分析が必要と される。このような観点から，本研究では， SDS-PAGE および抗ミオシン重鎖抗体を用い て，筋線維の収縮特性を規定し筋線維タイプを 決定しているミオシン重鎖のアインフォームに ついて分析を加えた。これにより，本研究で認 められた FOG 線維の増加が, SO 線維から FOG 線䧽へと移行したものであれば, 分子レべ ルにおいて速筋型ミオシン重鎖の増加が予測さ れる. 分析の結果, コントロール群では速筋型 ミオシン重鎖はほとんど確認されなかったのに 対し, 宙づり群では, 宙づり 3 週目以降はとん どのヒラメ筋で速筋型ミオシン重鎖の増加が認 められた。この速筋型ミオシン重鎖の増加は, 絶対量の増加によるものか，または相対的な割 合が増加したものかは分からない、しかしなが ら，各筇線維の萎縮の状態からみた場合，両筋 線維ともに $50 \%$ 前後の萎縮を示していること から, SO 線維の収樎蛋白 (遅筋型ミオシン) が 選択的に分解され，速筋型ミオシン量が相対的 に増加した可能性は低いと考えられる。した がって, 本結果は速筋型ミオシン重鎖の絶対量 が増加したものと推察される。この結果から， 本研究で認められた FOG 線維の増加は, SO 線 維から FOG 線維へ移行した可能性が示唆さ れ, 宙づりにより SO 線維は萎縮する一方で, そ の内部に速筋型ミオシン重鎖が合成されたこと により FOG 線維へとタイプ移行したものと推 察される。組織レベルと蛋白レベルから 宙づりによるヒラメ筋の速筋化が示唆された。

租織レベルと蛋白レベルの経時的变化の関連 性について検討したとき, 速筋型ミオシン重鎖 の増加と FOG 線維の増加との間には時間的な 遅延はみられず,同一時期に増加が認められた。 このことは, SO 線維から FOG 線維への移行期 の筋線維が, FOG 線維として分類された可能性 を示唆している。つまり, 宙づり期間中, SO 線 維から FOG 線維へとタイプ移行が完了する間 には, ある一定の移行期間が必要と考えられる。 この間，筋線維内には速筋タイプと遅筋タイプ 
のミオシン重鎖が混在し，時間経過にとすない 速筋タイブの重鎖の割合が増し，遅筋タイプの ミオシン重鎖が消失した時点でタイプ移行は完 了する。したがって，速㬳型のミオシン重鎖の 増加時期と, SO 線維から FOG 線維へのタイプ 移行が完了する時期には時間的な遅延が生じる と考えられる，逆に時間的な漣延が認められな いならば, SO 線䧽から FOG 線維への移行期の 笳線維 むFOG 線維として類別された可能性が 示唆される。このような移行期の筋線維に関し て, Fitts et al. ${ }^{10)}$ は, ラットに 2 週間の宙づり を施した結果，ヒラメ筋内に速筋型タイプのミ オシン分子種と易動度が類似した中間型ミオシ ン分子の增加を報告している. Gardetto et al. ${ }^{12}$ は， 2 週間の宙つりにより最大短縮速度が 29\%增加したヒラメ筋で，単一筋線䧽内に遅筋 型タイブと速筋型タイブ両方の分子種を含む混 在型線䊒の増加を認め,これが短縮速度の增加 に起因すると述べている。 また，Templeton et al. ${ }^{31}$ す同様な結果を得ており，そのような混在 型線維の割合が組織化学的に同定された Type IIa 線䊒の割合と近似であることから，混在型 線維は組織化学的には Type IIa 線稚として類 別されたものと推察している．本結果は，速筋 型ミオシン重鎖の増加と FOG 線維の増加の間 に時間的遅延は認められないことから，組織レ ベルで増加が認められた FOG 線䊒には, 移行 期の混在型線維も含まれる可能性があると考え られる。

本研究で用いた抗体は速筋型ミオシン重鎖の 検出には有奻であるが，反面そのサブタイブま では検討できない。これまでの HC-IIa，HC-IIb に加克，近年，ラットを用いた审気刺敏実 匰1,25,32)や宙つり実検29)により認められる新し い速筋型アイソフォーム (HC-IId，または HC$2 \mathrm{X})$ の分析についても今後の検討課題と考兄 られる。

\section{V. 䍃括}

本研究は, ラット尾部宙づりによるヒラメ筋 の筋線維組成および速筋型ミオシン重鎖分子種
の変化を検討することを目的とした。実験には ウイスター系雄性ラット 42 匹を用い，21匹ず つをコントロール群と宙づり群に分け，宙づり は尾部宙つりにより行った。 7 週間の実験期間 中，各週毎により 3 匹ずつを分析に供した。組 織化学的分析には左脚ヒラメ筋を，ミオシン重 鎖分析には右脚七ラメ筋を用いた。筋重量は， 宙づり 3 週目より顕著な低下が認められた。筇 線維横断面積も宙づり 3 週目より SO 線維, FOG 線維ともに䫒著な萎縮が認められ，その萎 縮は筋重量の低下と類似していることから，両 筋線維の萎縮が筋重田の低下に大きく起因する と考えられる。筋線維組成に威して,コントロー ル群のヒラメ筇 FOG 線䧽占有率は実検期間を 通して数\%であったのに対し，宙づり群では， 宙づり 3 週目以降のヒラメ筋において FOG 線 維占有率の増加が認められた。この結果と対応 して，宙づり 3 週目より速筋型ミオシン重鎖の 増加が認められた。これらのことから, 宙づり による FOG 線維の増加は, SO 線維からのタイ プ移行による可能性が示唆された。またこの よらな FOG 線䧽の增加は, 速筋型ミオンン重 鎖の増加を反映しており，組織レベルと蛋白レ ベルから宙づりによるラットヒラメ筋の速筋化 が推察された。

期辟：本稿の作成にあたり，貫重な御助言をいただき ました熊本大学医学部莱理学教室山本秀幸誏師に深䪭 いたします。

\section{文献（References）}

1) Barr, A. and Pette, D. (1988) Three fast myosin heavy chains in adult rat skeletal muscle. FEBS Lett. 235 : 153-155.

2) Bárány, M. (1967) ATPase activity of myosin correlated with speed of muscle shortening. J. Gen. Physiol. 50 : 197-218.

3) Billeter, R., Weber, H., Lutz, H., Howald, H., Eppenberger, H.M., and Jenny, E. (1980) Myosin types in human skeletal muscle fibers. Histochemistry $65: 349-259$.

4) Booth, F.W. and Kelso, J.R. (1973) Effect of hind-limb immobilization on contractile and his- 
tochemical properties of skeletal muscle. Pflügers Arch. 342 : 231-238.

5) Bradford, M.M. (1976) A rapid and sensitive method for the quantitation of microgram quantites of protein utilizing the principle of protein-dye binding. Anal. Biochem. 72 : 248-254.

6) Corley, K., Kowalchuk, N., and McComas, A.J. (1984) Contrasting effects of suspension on hindlimb muscles in the hamster. Exp. Neurol. $85: 30$ -40 .

7) Danieli-Betto, D., Zerabato, E., and Betto, R. (1986) Type 1, 2A, 2B myosin heavy chain electrophoretic analysis of rat muscle fibers. Biochem. Biophys. Res. Commun. 138 : 981-987.

8) Desplanches, D., Mayet, M.H., Sempore, B., and Flandrois, R. (1987) Structural and functional responses to prolonged hindlimb suspension in rat muscle. J. Appl. Physiol. 63 : 558-563.

9) Elder, G.C.B. and McComas, A.J. (1987) Development of rat muscle during short- and long-term hindlimb suspension. J. Appl. Physiol. 62: 1917 $-1923$.

10) Fitts, R.H., Metzger, J.M., Riley, D.A., and Unsworth, D.R. (1986) Models of disuse : A comparison of hindlimb suspension and immobilization. J. Appl. Physiol. 60 : 1946-1953.

11) Flynn, D.D. and Max, S.R. (1985) Effects of suspension hypokinesia/hypodynamia on rat skeletal muscle. Aviat. Space Environ. Med. 56 : 1065-1069.

12) Gardetto, P.R., Schulter, J.M., and Fitts, R.H. (1989) Contractile function of single muscle fibers after hindlimb suspensin. J. Appl. Physiol. 66 : 2739-2749.

13) Hauschka, E.O., Roy, R.R., and Edgerton, V.R. (1987) Size and metabolic properties of single muscle fibers in rat soleus after hindlimb suspension. J. Appl. Physiol. 62 : 2338-2347.

14) Jaspers, S.R. and Tischler, M.E. (1984) Atrophy and growth failure of rat hindlimb muscles in tail-cast suspension. J. Appl. Physiol. 57 : 1472 $-1479$.

15) Kasper, C.E., White, T.P., and Maxwell, L.C. (1990) Running during recovery from hindlimb suspension induces transient muscle injury. $\mathrm{J}$. Appl. Physiol. 68 : 533-539.

16) Laemmli, U.K. (1970) Cleavage of structural proteins during in the assembly of the head of bacteriophage T4. Nature (Lond.) 227 : 680-685.

17) Martin, T.P., Edgerton, V.R., and Grindeland, R. E. (1988) Influence of space flight on rat skeletal muscle. J. Appl. Physiol. 65 : 2318-2325.

18) Morey, E.R. (1979) Spaceflight and bone turnover: Correlation with a new rat model of weightlessness. Bioscience 29 : 168-172.

19) Nachlas, M.M., Walker, D.G., and Seligman, M. (1958) A histochemical method for the demonstration of diphosphopyridine nucleotide diaphorase. J. Biophysic. Biochem. Cytol. 4 : 29-43.

20) Padykula, H.A. and Herman, E. (1955) The specificity of the histochemical method for adenosine triphosphatase. J. Histochem. Cytochem. $3: 170-195$.

21) Perrie, W.T. and Bumford, S.J. (1986) Electrophoretic separation of myosin isoenzymes. Implications for the histochemical demonstration of fibre types in biopsy specimens of human skeletal muscle. J. Neurol. Sci. $73:$ 89-96.

22) Peter, J.B., Barnard, R.J., Edgerton, V.R., Gillespie, C.A., and Stempel, K.E. (1972) Metabolic profiles of three fiber types of skeletal muscle in guinea pigs and rabbits. Biochemistry $11 ; 2627$ $-2633$.

23) Reiser, P.J., Moss, R.L., Giulian, G.G., and Greaser, M.L. (1985) Shortening velocity in single fibers from adult rabbit soleus muscles is correlated with myosin heavy chain composition. J. Biol. Chem. 260 : 9077-9080.

24) Roy, R.R., Bello, M.A., Bouissou, P., and Edgerton, V.R. (1987) Size and metabolic properties of fibers in rat fast-twitch muscles after hindlimb suspension. J. Appl. Physiol. 62 ; 2348-2357.

25) Schiaffino, S., Ausoni, S., Gorza, L., Saggin, L., Gundersen, K., and Lomo, T. (1988) Myosin heavy chain isoforms and velocity of shortening of type 2 skeletal muscle fibres. Acta Physiol. Scand. $134: 575-576$.

26) Seedorf, K., Seedorf, U., and Pette, D. (1983) Coordinate expression of alkali and DTNB myosin light chains during transformation of rabbit fast muscle by chronic stimulaton. FEBS Lett. 158 : 321-324.

27) Sivaramakrishnan, M. and Burke, M. (1982) The free heavy chain of vertebrate skeletal myosin subfragment 1 shows full enzymatic activity. J. Biol. Chem. 257 : 1102-1105.

28) Stevens, L., Mounier, Y., Holy, X., and Falempin, M. (1990) Contractile properties of rat soleus muscle after 15 days of hindlimb suspension. J. Appl. Physiol. 68 : 334-340.

29) Takahashi, H., Wada, M., and Katsuta, S. (1991) Expressions of myosin heavy chain IId isoform in 
rat soleus muscle during hindlimb suspension. Acta Physiol. Scand. 143 : 131-132.

30) Templeton, G.H., Padalino, M., Manton, J., Glasberg, M., Silver, C.J., Silver, P., Demartino, G., Leconey, T., Klug, G., Hagler, H., and Sutko, J.L. (1984) Influence of suspension hypokinesia on rat soleus muscle. J. Appl. Physiol. 56 : 278-286.

31) Templeton, G.H., Sweeney, H.L., Timson, B.F., Padalino, M., and Dudenhoeffer, G.A. (1988) Changes in fiber composition of soleus muscle during rat hindlimb suspension. J. Appl. Physiol. 65 : 1191-1195.

32) Termin, A., Staron, R.S., and Pette, D. (1989) Myosin heavy chain isoforms in histochemically defined fiber types of rat muscle. Histochemistry 92 : 453-457.

33) Thomason, D.B., Herrick, R.E., Surdyka, D.D., and Baldwin, K.M. (1987) Time course of soleus muscle myosin expression during hindlimb suspension and recovery. J. Appl. Physiol. 63 : 130 -137 .

34) Towbin, H., Staehelin, T., and Gordon, J. (1979) Electrophretic transfer of proteins from polyacrylamide gels to nitrocellulose sheets: Procedure and some applications. Proc. Natl. Acad. Sci. (USA) 76 : 4350-4354.

（平成 4 年 3 月 9 日受付） 